\title{
Antimüllerhormon ved behandling av ufrivillig barnløshet
}

\author{
Sammendrag \\ Bakgrunn. Kvinner i Norge, som \\ i mange andre utviklede land, venter \\ lenger i dag med å få barn enn før. \\ Fruktbarheten hos kvinner synker med \\ alderen, spesielt etter 35 års alder. \\ Det har lenge vært behov for en bedre \\ markør av ovarial reserve og ovarial \\ respons ved behandling av ufrivillig \\ barnløshet. Denne artikkelen gir en \\ oversikt over fysiologisk utvikling av \\ follikler i eggstokkene og den spesielle \\ plassen antimüllerhormon har i denne \\ prosessen.
}

Materiale og metode. Det ble gjort ikke-systematisk litteraturs $ø$ k for relevante artikler i PubMed, Athens og Embase.

Resultater. Nivået av antimüllerhormon er relativt stabilt gjennom menstruasjonssyklusen, og hormonet synes å være en pålitelig markør for ovarial respons. Bestemmelse av hormonnivået vil kunne identifisere kvinner med høy risiko for avvikende respons ved ovarial stimulering.

Fortolkning. Klinisk bruk av antimüllerhormon er først og fremst aktuelt ved utredning og behandling av ufrivillig barnløshet.

\author{
Gurpreet Singh Kalra \\ gsk@doctors.org.uk \\ Department of Obstetrics and Gynaecology \\ St. Michael's Hospital \\ Southwell Street \\ Bristol BS2 8EG
}

Kvinner er stadig eldre når de føder sitt første barn. De har dermed færre fruktbare år til disposisjon for barnefødsler. Ifølge tall fra Medisinsk fødselsregister var gjennomsnittsalderen for norske kvinner da de fikk sitt første barn 28,1 år i perioden 2005-06. Gjennomsnittsalderen hadde økt med nesten tre år fra perioden 1986-90, da den var 25,2 år. Opptil $20 \%$ av alle kvinner i Norge føder sitt første barn ved eller etter 35 års alder (1).

Ovarial reserve kan sies å være et uttrykk for antallet follikler som til enhver tid er igjen i ovariene og kvaliteten på eggene i disse folliklene (2). Begrepet er nært knyttet til ovarial respons, som beskriver hvor lett ovariene lar seg stimulere ved hjelp av follikkelstimulerende hormon (FSH), for eksempel ved in vitro-fertilisering.

For å vurdere ovarial reserve eller ovarial respons brukes blant annet kliniske parametere som kvinnens alder og kroppsmasseindeks og endokrine markører som follikkelstimulerende hormon, luteiniserende hormon (LH), inhibin B og østradiol. I tillegg utføres rutinemessig ultralydundersøkelse av eggstokkene for å bestemme antallet antrale follikler. Både follikkelstimulerende hormon, luteiniserende hormon, østradiol og inhibin B er upålitelige markører i denne sammenheng. Disse hormonene er dessuten avhengig av å bli målt tidlig i follikulær fase. Antallet antrale follikler har derimot vist seg å være en relativt bra markør for ovarial respons ved assistert befruktning (3).

En god markør for ovarial reserve og ovarial respons som kan bestemmes i en blodprøve, har lenge vært etterspurt. Antimüllerhormon (AMH) ser ut til å kunne være en slik markør.

\section{Materiale og metode}

Det ble gjort et ikke-systematisk litteratursøk for relevante artikler i databasene PubMed og Embase samt Athens (portal som gir felles tilgang til mange helseinformasjonsressurser, blant annet tidsskrifter i fulltekst).

\section{Historie og egenskaper}

Antimüllerhormon har tradisjonelt vært kjent som et hormon som forårsaker regresjon av de müllerske ganger i guttefostre $\mathrm{i}$ det tidlige fosterstadiet. I 1953 publiserte franskmannen Alfred Jost sitt historiske arbeid der han viste at det var andre hormoner enn testosteron som forårsaket regresjon av de müllerske gangene hos guttefostre. Han kalte hormonet inhibitrice, senere kalt antimüllerhormon (4). I 1986 ble det påvist at antimüllerhormon også finnes i granulosacellene i folliklene i eggstokkene fra litt før fødselen og inntil menopause (4).

Antimüllerhormon hører til den transformerende vekstfaktor- $\beta$-superfamilien og har en molekylvekt på ca. 140000 dalton. Humant antimüllerhormon produseres som et preprohormon med 560 aminosyrer (5). Dette ble første gang fremstilt i ren form i 1984 av Picard \& Josso (6). Genet for antimüllerhormon ble isolert først i 1986 (7). Genet ligger på den korte armen av kromosom 19 og er 2750 basepar langt (7). En ligandspesifikk reseptor for antimüllerhormon, kalt $\mathrm{AMH}-$ reseptortype II (AMHRII), ble identifisert i 1994. Kandidater til type I-reseptor, som danner et kompleks med AMHRII, er identifisert, men en unik AMH-type I-reseptor er ikke funnet (8). Det er påvist mRNA for både antimüllerhormon og AMHRII eksklusivt i Sertoli-cellene hos menn og i granulosacellene hos kvinner. Dette tyder på at det foreligger autokrine virkningsmekanismer relatert til antimüllerhormon. Disse mekanismene er sannsynligvis viktige for spermatogenesen og follikulogenesen. I tillegg uttrykkes AMHRII i de müllerske gangene $\mathrm{i}$ et begrenset tidsrom i uke 6-9 av fosterstadiet. I løpet av dette tidsrommet produseres antimüllerhormon kun i Sertoli-cellene, der hormonet fremmer regresjon av de müllerske gangene hos guttefostre (9-11).

\section{Ovarial reserve og fruktbarhet}

Kvinnelig fruktbarhet er avhengig av mange forhold, hvorav størrelse på ovariets follikkelkohort er en viktig faktor. Antall follikler er

\section{Hovedbudskap}

- Konsentrasjonen av antimüllerhormon er relativt stabil under hele menstruasjonssyklusen

- Antimüllerhormon fremstår som en pålitelig markør for ovarial respons

- Antimüllerhormon synes å være et viktig hjelpemiddel ved assistert befruktning 


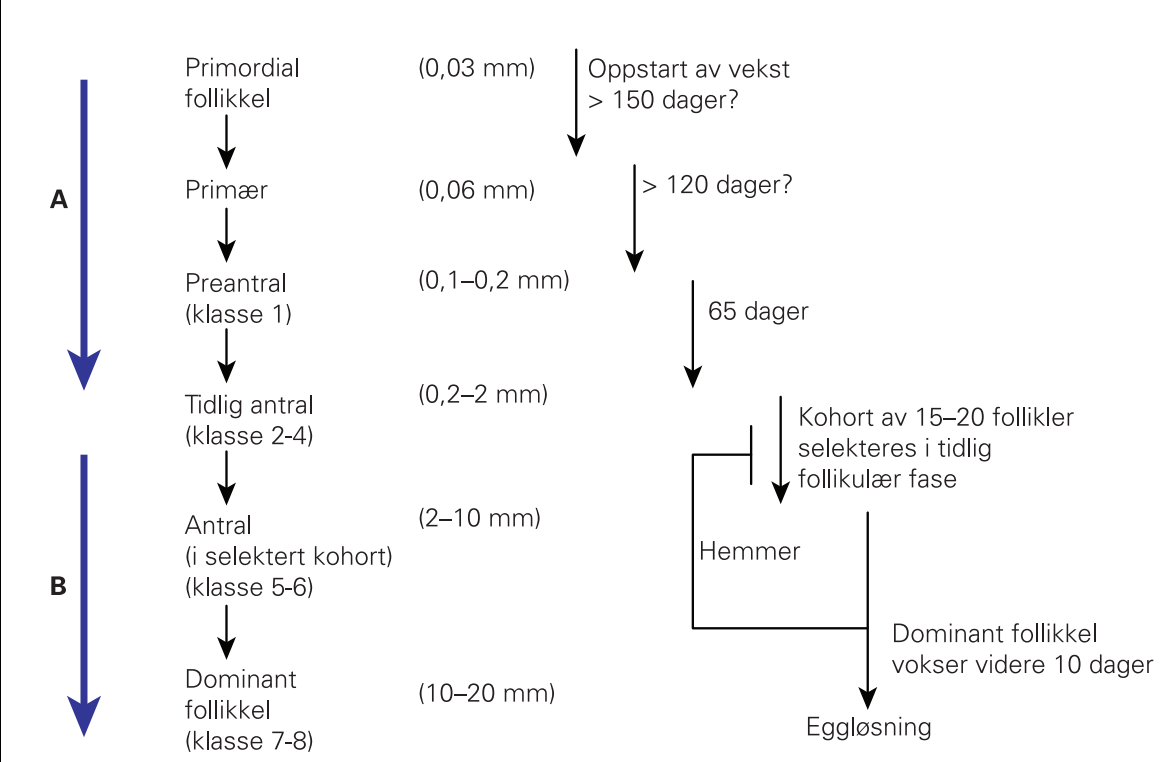

Figur 1 Follikkel gjennom forskjellige utviklingsstadier. A = gonadotropinuavhengig stadium, $B=$ gonadotropinavhengig stadium (starter først etter pubertet)

genetisk bestemt og blir dannet $\mathrm{i}$ ovariene $\mathrm{i}$ fosterstadiet. Fra maksimum antall ved rundt 20. svangerskapsuke er det en kontinuerlig reduksjon i antallet follikler frem til menopause. Denne inntreffer stort sett på grunn av genetisk programmert celledød (atresi), men reduksjonen skjer også til en viss grad på grunn av eggløsninger. Fra menarke av er det ca. 1000 follikler som forsvinner hver måned (12). Det er vist at alder ved menopause er avhengig av det totale antallet follikler i ovariene og hvor raskt antallet reduseres (13). Kjente risikofaktorer for redusert ovarial reserve, $i$ tillegg til genetiske faktorer, er røyking, kirurgiske inngrep som affiserer eggstokkene, bekkeninfeksjon, endometriose, kjemoterapi og stråleterapi (13).

Hos de fleste er reduksjonen i antall follikler nesten stabil opptil en alder av ca. 37,5 år, da det gjennomsnittlig finnes en kohort på omtrent 25000 follikler igjen i eggstokkene.
Etter at denne kritiske terskelen er nådd, blir hastigheten på programmert celledød nesten fordoblet $(14,15)$. Det har lenge vært kjent at tap av follikler har en invers relasjon til det totale antallet follikler som er igjen i ovariene til enhver tid. I reproduksjonssammenheng gjenspeiles dette ved at sjansen til å oppnå graviditet hos mange kvinner er vesentlig redusert etter 35-årsalderen på grunn av et lavt antall gjenværende follikler (16). En annen ugunstig faktor i reproduksjonssammenheng er at mange av eggene som modnes i høy reproduktiv alder, ofte er av redusert kvalitet sammenliknet med de eggene som ble dannet i tidlig fertil alder. Dette er forårsaket av en sterk økning i forekomsten av aneuploidi fra ca. $36-37$ års alder (17).

\section{Antimüllerhormon og follikler}

Follikkelmodningen kan beskrives i ulike utviklingsstadier basert på Gougeons klassi-

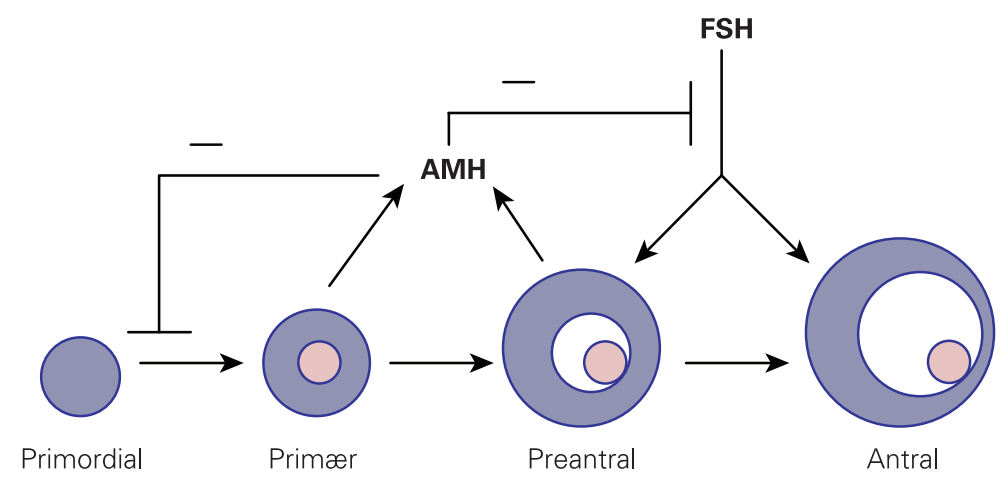

Figur 2 Modell av antimüllerhormons effekt på follikkelutviklingen. Antimüllerhormon produseres i de primære, sekundære, preantrale og tidlig antrale folliklene. Hormonet har en hemmende effekt på initiell follikkelmodning fra primordialfolliklene, samtidig som det hemmer FSH-avhengig vekst av de preantrale og de små antrale folliklene fikasjon fra 1986 (18). Folliklene kan deles inn i primordialfollikler, primære follikler, sekundære follikler, preantrale follikler, antrale follikler (klasse 2-7) og preovulatoriske follikler (klasse 8). Disse blir klassifisert etter størrelse, utvikling av støttecellene rundt oocytten og tilstedeværelse av væskefylt kavitet (antrum) (18). Zona pellucida dannes i overgangen fra primordial til primær follikkel.

Follikkelutviklingen kan deles inn $\mathrm{i}$ to hovedfaser. Den første er gonadotropinuavhengig, mens den andre fasen er gonadotropinavhengig (fig 1). Allerede fra fosterstadiet starter folliklene å utvikle seg i grupper, men de kommer ikke lenger enn til det tidlige antralstadiet (klasse 4). Dette skyldes at gonadotropiner er nødvendige for den videre utviklingen, noe som betyr at før puberteten ender disse folliklene i celledød. Når puberteten inntrer, vil sekresjonen av gonadotropiner fra hypofysen blant annet føre til at en kohort av follikler (ca. 15-20) utvikles hver måned. Av disse vil én dominant follikkel normalt gjennomgå eggløsning av ett modent egg, mens de andre gjennomgår programmert celledød $(13,18)$.

Antimüllerhormon produseres hovedsaklig i preantrale og tidlig antrale follikler, men også i mindre grad i primære og sekundære follikler $(19,20)$. Hormonet produseres ikke i primordialfolliklene, de store antrale folliklene ( $>$ klasse 5), de atretiske folliklene, thecacellene eller oocytten (21-24). Dette betyr at antimüllerhormon dannes eksklusivt av gonadotropinuavhengige follikler under tidlig utvikling. Nivået av antimüllerhormon gjenspeiler derfor antallet follikler i tidlig utvikling til enhver tid i eggstokkene, helt fra fødsel til menopause $(21,22,24)$. Antallet follikler i tidlig utvikling er igjen et uttrykk for det totalet antallet folliker i ovariene.

I biologisk sammenheng synes antimüllerhormon å hemme tidlig follikulær vekst og å hemme virkningen av follikkelstimulerende hormon i senere stadier av follikkelutviklingen (fig 2) $(21,22,24)$.

\section{Bedre markør for ovarial respons}

Konsentrasjonen av antimüllerhormon i serum varierer relativt lite i forskjellige stadier av menstruasjonssyklus og viser god reproduserbarhet fra syklus til syklus (25). Konsentrasjonen i perifert blod viser et tilnærmet lineært fall etter hvert som det totale antallet follikler reduseres og kvinnens fertile alder øker $(22,23)$. Reduksjonen av antimüllerhormon kan oppdages lenge før andre markører viser et nivå som kan indikere redusert ovarial reserve (22). Nivået av antimüllerhormon er i flere studier vist å ha en meget god korrelasjon til antallet antrale follikler som kan påvises ved ultralyd (24, 26). Man vet fra tidligere at antallet antrale follikler er en god markør for det totale antallet follikler som er igjen i ovariene til enhver tid (27-29). 
Nivået av antimüllerhormon i serum kan i prinsippet måles når som helst $\mathrm{i}$ menstruasjonssyklus. I Norge er det imidlertid fortsatt ingen laboratorier som analyserer dette hormonet.

\section{Klinisk bruk}

I klinisk sammenheng blir antimüllerhormon allerede brukt rutinemessig i flere land som en predikator for ovarial respons i forbindelse med utredning og behandling av ufrivillig barnløshet. Antimüllerhormon tas som oftest i tillegg til de vanlige markørene. Derved får man best mulig informasjon om ovarial reserve, noe som vil kunne gjøre at stimuleringen av eggstokkene i forbindelse med assistert befruktning blir så optimal som mulig. Hos kvinner med svært lavt hormonnivå vil det derimot ikke ha noen hensikt å forsøke med medikamentell stimulering av eggstokkene, fordi man vet at ovarialresponsen vil bli dårlig.

Kvinner med polycystisk ovarie-syndrom (PCOS) har karakteristisk serumnivå av antimüllerhormon som er 2-3 ganger høyere enn hos kvinner som ikke har syndromet. Bestemmelse av antimüllerhormon kan derfor være til hjelp for å identifisere pasienter i denne gruppen. Dette er viktig i klinisk sammenheng, siden kvinner med polycystisk ovarie-syndrom har økt risiko for ovarial hyperstimulering ved assistert befruktning sammenliknet med kvinner flest (30-32).

I flere land tilbys kvinner som ønsker å vente med å få barn, å få målt nivået av antimüllerhormon. Hvis hormonnivået synker raskt eller begynner å bli lavt, finnes det tilbud om å fryse ned ubefruktede egg som senere kan befruktes, eller man kan velge å få eggene befruktet med donorsæd eller partnersæd for så å fryse dem ned til et mer beleilig tidspunkt for graviditet.

En svakhet med antimüllerhormon er at blodprøven sier lite om kvaliteten til de eggene som modnes ved ovarial stimulering. I klinisk praksis betyr dette at selv om man klarer å få tak i egg hos mange kvinner i høy reproduktiv alder, vil en stor andel av eggene ikke være av en slik kvalitet at man oppnår ukomplisert graviditet.

\section{Konklusjon}

Antimüllerhormon synes å være en god markør for ovarial respons. Konsentrasjonen av antimüllerhormon i perifert blod er nokså stabil gjennom menstruasjonssyklusen og affiseres ikke av graviditet. Ved å måle antimüllerhormon kan man identifisere kvinner som har høy risiko for dårlig respons eller for å utvikle ovarialt hyperstimuleringssyndrom ved assistert befruktning. Dermed kan man tilby en bedre og mer individuelt tilpasset stimulering av ovariene, noe som igjen øker sjansen for ukomplisert fertilitetsbehandling og vellykket graviditet.

Oppgitte interessekonflikter: Ingen
Litteratur

1. Medisinsk fødselsregister. Fruktbarhet, fødealder og helse - faktaark. www.mfr.no (18.2.2008)

2. Broekmans FJ, Kwee J, Hendriks DJ et al. A systematic review of tests predicting ovarian reserve and IVF outcome. Hum Reprod Update 2006; 12: $685-718$

3. De Vet A, Laven JS, de Jong FH et al. Antimüllerian hormone serum levels: a putative marker for ovarian ageing. Fertil Steril 2002; 77: 357-62.

4. Jost A. Problems of fetal endocrinology: the gonadal and hypophyseal hormones. Recent Prog Horm Res 1953; 8: 379-418.

5. Rey R, Lukas-Croisier C Lasala C et al. AMH/MIS what we know already about the gene, the protein and its regulation. Mol Cell Endocrinol 2003; 211: $21-31$.

6. Picard JY, Josso N. Purification of testicular antimüllerian hormone allowing direct visualisation of the pure glycoprotein and determination of yield and purification factor. Mol Cell Endocrinol 1984; 34: $23-9$.

7. Cate RL, Mattaliano RJ, Hession C et al. Isolation of the bovine and human genes for Müllerian inhibiting substance and expression of human gene in animal cells. Cell 1986; 45: 685-98.

8. Josso N di Clemente N. Transduction pathway of anti-Müllerian hormone, a sex specific member of TGF- $\beta$ family. Trends Endocrinol Metab 2003; 14: $91-7$.

9. Takahashi M, Hayashi M, Manganaro TF et al. The ontogeny of mullerian inhibiting substance in the granulosa cells of the bovine ovarian follicle. Biol Reprod 1986; 35: 447-53.

10. Baarends WM, Uilenbroek J, Kramer P et al. Antimüllerian hormone and anti-müllerian hormone type II receptor messenger ribonucleic acid expression in rat ovaries during postnatal development, the estrous cycle, and gonadotropininduced follicle growth. Endocrinology 1995; 136: 4951-62.

11. Baarends WM, Hoogerbrugge J, Post M et al. Antimüllerian hormone and anti-müllerian hormone type II receptor messenger ribonucleic acid expression during postnatal testis development and in the adult testis of the rat. Endocrinology 1995: 136: 5614-22

12. Fauser B, Van Heusden AM. Manipulation o human ovarian function: physiological concepts and clinical consequences. Endocr Rev 1997; 18 $71-106$

13. Nikolaou D, Templeton A. Early ovarian aging a hypothesis. Detection and clinical relevance. Hum Reprod 2003; 18: 1137-9.

14. Faddy MJ, Gosden RG, Gougeon A et al. Accelerated disappearance of ovarian follicles in midlife: implications for forecasting menopause. Hum Reprod 1992; 7: 1342-6.

15. Faddy MJ, Gosden RG. A model conforming the decline in follicle numbers to the age of menopause in women. Hum Reprod 1996; 11: 1484-6.

16. te Velde ER, Pearson PL. The variability of female reproductive aging. Hum Reprod Update 2002; 8: $141-54$

17. Pellestor F, Andréo B, Anahory T et al. The occurrence of aneuploidy in human: lessons from the cytogenetic studies of human oocytes. Eur J Med Genet 2006; 49: 103-16

18. Gougeon A. Dynamics of follicle growth in the human: a model from preliminary results. Hum Reprod 1986; 1: 81-7

19. Weenen C, Laven JS, Von Bergh AR et al. AntiMüllerian hormone expression pattern in the human ovary: potential implications for the initial and cyclic follicle recruitment. Mol Hum Reprod 2004: 10: $77-83$

20. Hirobe S, He WW, Gustafson ML et al. Müllerian inhibiting substance gene expression in the cycling rat ovary correlates with recruited or graafian follicle secretion. Biol Reprod 1994; 50: $1238-43$

21. Visser JA, de Jong FH, Laven JS et al. Anti-Müllerian hormone: a new marker for ovarian function. Reproduction 2006; 131: 1-9.

22. La Marca A, Volpe A. Anti-Müllerian hormone (AMH) in female reproduction: is measurement of circulating $\mathrm{AMH}$ a useful tool? Clin Endocrinol 2006; 64: 603-10.

23. Tremellen KP, Kolo M, Gilmore A et al. Anti-mullerian hormone as a marker of ovarian reserve. Aust N Z J Obstet Gynaecol 2005; 45: $20-4$
24. van Rooij IA, Broekmans FJ, te Velde ER et al. Serum anti-Müllerian hormone levels: a novel measure of ovarian reserve. Hum Reprod 2002; 17: $3065-71$.

25. Fanchin R, Taieb J, Lozano DH et al. High reproducibility of serum anti-Mullerian hormone measurements suggests a multi-staged follicular secretion and strengthens its role in assessment of ovarian follicular status. Hum Reprod 2005; 20 : $923-7$

26. Fanchin R, Schonäuer LM, Righini C et al. Serum anti-Müllerian hormone is more strongly related to ovarian follicular status than serum inhibin B. estradiol, FSH and LH on day 3. Hum Reprod 2003. 18: $323-7$

27. Gougeon A, Ecochard R, Thalabard JC. Age-related changes of the population of human ovarian follicles: increase in the disappearance rate of non-growing and early-growing follicles in aging women. Biol Reprod 1994; 50: 653-63.

28. Ruess ML, Kline J, Santos R et al. Age and ovarian follicle pool assessed with transvaginal ultrasonography. Am J Obstet Gynecol 1996; 174: 624-7.

29. Kevenaar ME, Meerasahib MF, Kramer $P$ et al. Serum anti-mullerian hormone levels reflect the size of primordial follicle pool in mice. Endocrinology 2006; 147: 3228-34.

30. Franks S. Polycystic ovarian syndrome. N Engl J Med 1995; 333: 853-61.

31. Pigny P, Merlen E, Robert Y et al. Elevated serum level of anti-mullerian hormone in patients with polycystic ovary syndrome: relationship to the ovarian follicle excess and to the follicular arrest. J Clin Endocrinol Metab 2003; 88: 5957-62.

32. Pigny $P$, Jonard S, Robert $Y$ et al. Serum anti-Mullerian hormone as a surrogate for antral follicle count for definition of the polycystic ovarian syndrome. J Clin Endocrinol Metab 2006: 91: 941 -5.

Manuskriptet ble mottatt 23.1. 2008 og godkjent 19.12. 2008. Medisinsk redaktør Trine B. Haugen. 